\title{
Coverage of the Genetic Background of Breast Cancer in the Polish Population
}

\author{
Pablo Serrano-Fernández, Bohdan Górski, Tadeusz Dębniak, Cezary Cybulski, Tomasz Byrski, Tomasz Huzarski, Jacek Gron- \\ wald, Anna Jakubowska, Oleg Oszurek, Jan Lubiński, Polish Hereditary Cancer Consortium
}

International Hereditary Cancer Center, Połabska 4, 70-115 Szczecin, Poland

Key words: BRCA1, BRCA2, CHEK2, NOD2, p16, NBS1, breast cancer

Corresponding author: Pablo Serrano-Fernandez, International Hereditary Cancer Center, Pomeranian Medical Univeristy, ul. Połabska 4, 70-115 Szczecin, Poland; e-mail: albifrons@yahoo.com

Submitted: 15 0ctober 2005

Accepted: 15 Nobember 2005

\section{Background}

It is a known fact that cancer risk is influenced by both environmental and genetic factors. Parameters such as the kind and site of the tumour and family history depend on the proportion between both and the population determines to a great extent the characteristics of the genetic background. Here we focus on breast cancer in the Polish population.

Despite complex population dynamics in the last centuries, the Poles seem to be surprisingly homogeneous in their genetics. A sequence-based screening of BRCA1 positive patients showed just 9 polymorphisms of BRCA1, where $91 \%$ of individuals shared just 3 common founder mutations [1]. The result is consistent with other Slavic countries [2-4]. In contrast, a similar screening in neighbouring Germany revealed 77 distinct BRCA1 mutations, 18 of them shared by $68 \%$ of BRCA1 positive patients [5].

Highly penetrating mutations, such as those of $B R C A 1$, are mostly detected in conspicuous family aggregations via genetic linkage studies. Therefore, they may be detected with the help of just a few families even in heterogeneous populations. However, the probability of finding a new highly penetrating gene for the Polish population seems rather low; mutations of BRCA1 and BRCA2 already cover $\sim 70 \%$ of cases of strong familial aggregations of breast and ovarian cancers [1]. The advantage of genetically homogeneous populations relies instead on the increased power of finding medium- and low-risk markers via large association studies that would otherwise be blurred in more complex populations.

\section{Results}

To date several variants of 6 genes have been demonstrated to significantly increase breast cancer risk in the Polish population: BRCA1, BRCA2, CHEK2, NBS1, NOD2, P16 [1, 6-9]. They actually cover $\sim 25 \%$ of early onset ( $<50$ yrs) breast cancer cases $(n=3000)$. Current investigations extend those 6 genes up to 9 (data in preparation) (Fig. 1). One of them, represented as X2, includes a common variant that improves the total coverage up to $80 \%$ in a pre-

\section{Coverage of breast cancer cases}

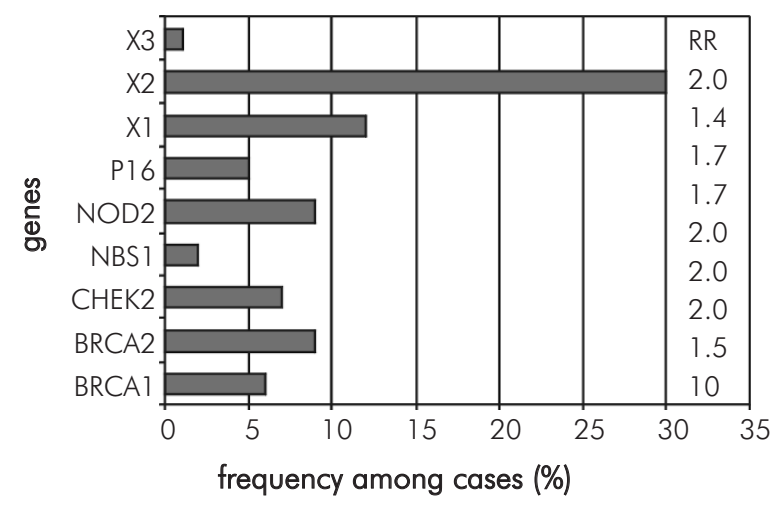

Fig. 1. Frequency of different genes with variants associated with breast cancer as covering a population of 3000 early onset ( $<50$ yrs) breast cancer patients. Genes represented as X1-X3 are still subject of study and their values refer to estimations from preliminary data. Most of the genes represented include several disease-associated variants. The last column stands for the relative risk of each of them 
liminary analysis: 700 cases out of 850 showed at least one disease-associated variant of the 9 analysed genes (Fig. 2).

Those values should drop for cases with onset at older ages as the cumulative exposure to external carcinogenic agents increases. Nevertheless, in familial aggregations of breast and ovarian cancer that percentage is expected to be higher since just BRCAl and

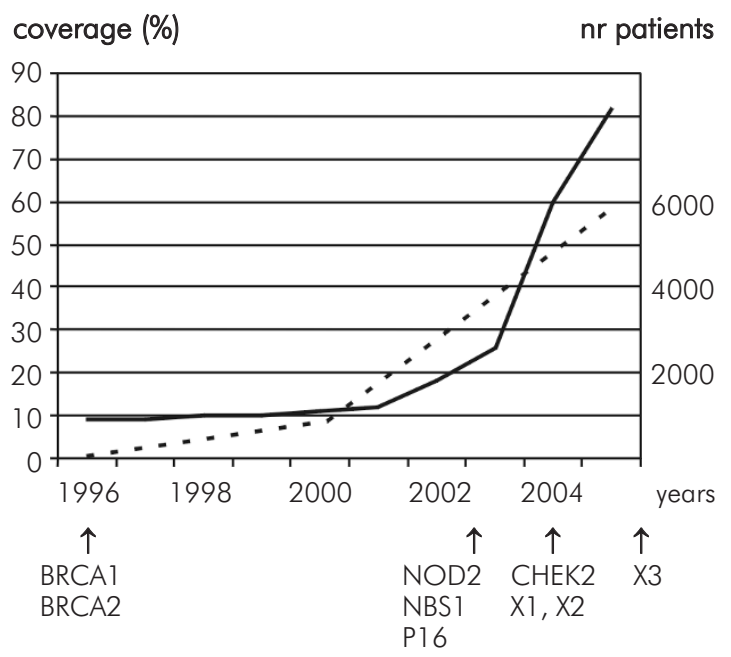

Fig. 2. Time sequence of the growth of the sample database (dashed line) in number of patients (note: the number of genotyped samples is actually 3500) and the improvement of the coverage of diseaseassociated genetic factors in the same population (continuous line). The percentage of coverage is based on estimations for different numbers of patients depending on the specific genes involved: 3000 patients for BRCA1, BRCA2, CHEK2, NBS1, NOD2 and P16; and 850 patients for those genes and the ones referred as $X 1, X 2$ and $X 3$ (currently under study). The approximately onset of systematic analyses for the respective genes is indicated with an arrow and the gene's acronym

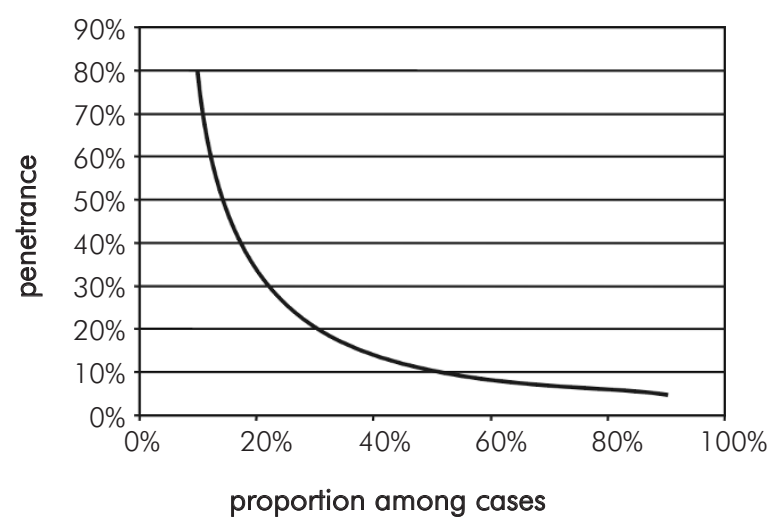

Fig. 3. Ideographic representation of the relationship between penetrance of the predisposing genetic factors and the proportion of the population of patients they are present in. Genes with highest penetrance are rather uncommon, in contrast to those with low penetrance, which can be very frequent. However, the interaction between different low penetrance factors may again increase the penetrance of the compound
BRCA2 account already for almost $70 \%$ of cases. Both analyses have still to be performed.

\section{Conclusions}

The Polish population appears to be a useful group for detecting low-risk markers of cancer. It is large $(\sim 40 \mathrm{~m})$ and homogeneous enough to reach the statistical power necessary to detect small but still significant differences in cancer risk. Our actual knowledge of disease-associated genetic factors present in breast cancer cases is $\sim 70 \%$ for familial aggregations and $\sim 80 \%$ for early onset consecutive cases. Thanks to the parallel growth of the network country-wide for sample and data exchange and the genetic variants under analysis, we expect to approach 100\% in the near future.

But even in such a scenario, the detection of a single predisposing genetic factor does not exclude the presence of additional ones. In fact, the current model predicts that the interplay between several genetic factors of low penetrance when analysed separately may increase the risk (either additively or synergically) to values comparable to much more penetrating ones (Fig. 3) [10]. Therefore, the search for new low-risk markers should continue even beyond the theoretical $100 \%$ of coverage, and bioinformatic analyses of the interplay among these factors should improve their application in clinical practice.

\section{References}

1. Gorski B, Jakubowska A, Huzarski T, Byrski T, Gronwald J, Grzybowska E, Mackiewicz A, Stawicka M, Bebenek M, Sorokin D, Fiszer-Maliszewska L, Haus O, Janiszewska H, Niepsuj S, Gozdz S, Zaremba L, Posmyk M, Pluzanska M, Kilar E, Czudowska D, Wasko B, Miturski R, Kowalczyk JR, Urbanski K, Szwiec M, Koc J, Debniak B, Rozmiarek A, Debniak T, Cybulski C, Kowalska E, Toloczko-Grabarek A, Zajaczek S, Menkiszak J, Medrek K, Masoic B, Mierzejewski M, Narod SA and Lubinski J. A high proportion of founder BRCA1 mutations in Polish breast cancer families. Int J Cancer 2004; 110: 683-686.

2. Machackova E, Foretova L, Navratilova M, Valik D, Claes K and Messiaen L. A high occurrence of BRCA1 and BRCA2 mutations among Czech hereditary breast and breast-ovarian cancer families. Cas Lek Cesk 2000; 139: 635-637.

3. Csokay B, Tihomirova L, Stengrevics A, Sinicka O and Olah E. Strong founder effects in BRCAl mutation carrier breast cancer patients from Latvia. Mutation in brief no. 258. Online. Hum Mutat 1999; 14: 92.

4. Oszurek O, Gorski B, Gronwald J, Prosolow Z, Uglanica K, Murinow A, Bobko I, Downar O, Zlobicz M, Norik D, Byrski T, Jakubowska $A$ and Lubinski J. Founder mutations in the BRCA 1 gene in west Belarusian breast-ovarian cancer families. Clin Genet 2001; 60: 470-471.

5. Meindl A and German Consortium for Hereditary Breast and Ovarian Cancer. Comprehensive analysis of 989 patients with 
breast or ovarian cancer provides BRCA1 and BRCA2 mutation profiles and frequencies for the German population. Int J Cancer 2002; 97: 472-480.

6. Gorski B, Cybulski C, Huzarski T, Byrski T, Gronwald J, Jakubowska A, Stawicka M, Gozdecka-Grodecka S, Szwiec M, Urbanski K, Mitus J, Marczyk E, Dziuba J, Wandzel P, Surdyka D, Haus $\mathrm{O}$, Janiszewska H, Debniak T, Toloczko-Grabarek A, Medrek K, Masojc B, Mierzejewski M, Kowalska E, Narod SA and Lubinski J. Breast cancer predisposing alleles in Poland. Breast Cancer Res Treat 2005; 92: 19-24.

7. Huzarski T, Lener M, Domagala W, Gronwald J, Byrski T, Kurzawski G, Suchy J, Chosia M, Woyton J, Ucinski M, Narod SA and Lubinski J. The 3020insC allele of NOD2 predisposes to early-onset breast cancer. Breast Cancer Res Treat 2005; 89: 91 -93.

8. Debniak T, Gorski B, Huzarski T, Byrski T, Cybulski C, Mackiewicz A, Gozdecka-Grodecka S, Gronwald J, Kowalska E, Haus O,
Grzybowska E, Stawicka M, Swiec M, Urbanski K, Niepsuj S, Wasko B, Gozdz S, Wandzel P, Szczylik C, Surdyka D, Rozmiarek $A$, Zambrano O, Posmyk $M$, Narod SA and Lubinski J. A common variant of CDKN2A ( 16 ) predisposes to breast cancer. J Med Genet 2005; 42: 763-765.

9. Cybulski C, Gorski B, Huzarski T, Masoic B, Mierzejewski M, Debniak T, Teodorczyk U, Byrski T, Gronwald J, Matyjasik J, Zlowocka E, Lenner M, Grabowska E, Nej K, Castaneda J, Medrek K, Szymanska A, Szymanska J, Kurzawski G, Suchy J, Oszurek O, Witek A, Narod SA and Lubinski J. CHEK2 is a multiorgan cancer susceptibility gene. Am J Hum Genet 2004; 75: 1131 - 1135.

10. Lubinski J. Familial Cancer Epidemiology: Common and Rare Inherited Cancer Syndromes, Family Cancer Database, Madrid 06.05.2004, Conference of the European School of Oncology.

\section{The Polish Hereditary Cancer Consortium are (in alphabetical order):}

Byrski T (1), Castaneda J (1), Cybulski C (1), Czajka R (2), Dębniak T (1), Domagała W (3), Dziuba J (1), Gliniewicz B (7), Górski B (1), Gozdecka-Grodecka S (10), Grabowska-Kłujszo E (4), Gronwald J (1), Haus $O(1$ 1), Huzarski T (1), Jakubowska A (1), Janiszewska H (1 1), Kowalska E (1), Kurzawski G (1), Lener M (4), Lubiński J (1), Marczyk E (12), Masoić B (1), Matyjasik J (1), Mędrek K (1), Mierzejewski M (1), Mituś J (12), Narod SA (6), Nej-Wołosiak K (4), Oszurek O (1), Posmyk M (8), Scott R (13), Serrano-Fernandez P (1), Sikorski A (14), Stawicka M (15), Suchy J (1), Surdyka D (16), Szwiec M (9), Szymańska A (1), Szymańska-Pasternak J (1), Teodorczyk U (1), Tołoczko-Grabarek A (1), Urbański K (12), Wandzel P (17), Witek A (5), Woyke S (3), Złowocka E (1).

1. International Hereditary Cancer Center. Połabska 4, 70115 Szczecin, Poland.

2. Department of Obstetrics and Perinatology, Pomeranian Medical University, Szczecin, Poland.

3. Department of Pathology, Pomeranian Medical University, Szczecin, Poland.

4. Inter-University Unit of Molecular Biology, University of Szczecin and Pomeranian Medical University, Szczecin, Poland.

5. Medical University of Silesia, Katowice, Poland.

6. Centre for Research on Women's Health, Toronto, Canada.

7. Clinic of Urology, Pomeranian Academy of Medicine, Szczecin, Poland.

8. Regional Oncology Hospital, Białystok, Poland.

9. Regional Oncology Hospital, Olsztyn, Poland.

10. Poznan Medical University, Poland.

11. Department of Clinical Genetics, Bydgoszcz Medical University, Poland.

12. Regional Oncology Center, Kraków, Poland.

13. Discipline of Medical Genetics, Faculty of Health, University of Newcastle, Hunter Medical Research Institute, NSW, Australia.

14. Department of Urology, Pomeranian Medical University, Szczecin, Poland.

15. Prophylactic and Epidemiology Center, Poznań, Poland.

16. Regional Oncology Hospital, Lublin, Poland.

17. Regional Oncology Hospital, Bielsko Biała, Poland. 